\title{
DNA Hybridization Detection with Blue Luminescent Quantum Dots and Dye-Labeled Single-Stranded DNA
}

\author{
Hui Peng, Lijuan Zhang, Tanja H. M. Kjällman, Christian Soeller, and Jadranka Travas-Sejdic* \\ Polymer Electronic Research Centre, The University of Auckland, Private Bag 92019, Auckland, New Zealand
}

Received November 28, 2006; E-mail: j.travas-sejdic@auckand.ac.nz

Quantum dots (QDs) have become an important photonic tool in the past two decades due to their unique properties, such as high chemical stability, resistance to photodegradation, and readily tunable optical properties. ${ }^{1-3}$ QD colloids are often prepared using organometallic routes at high temperature. ${ }^{4-6}$ The most widely used surface-capping ligands are trioctylphosphine/trioctylphosphine oxide (TOP/TOPO) and long-chain alkylamine. The resulting QDs are hydrophobic, and further chemical modifications are generally required for compatibility with biological applications. Since the first reports on the designs of hydrophilic QDs and QD-protein conjugates, ${ }^{1,2}$ a number of surface functionalization schemes have been developed to make QDs water soluble and thus suitable for biological applications..$^{3,7,8}$ An alternative approach is to synthesize QDs directly in an aqueous medium. Since the original report on the aqueous synthesis of mercaptoethanol- and thioglycerol-capped CdTe QDs, ${ }^{9}$ significant progress has been made in the preparation of thiol-capped CdTe QDs that exhibit very stable luminescence. ${ }^{10}$

Due to their tunable narrow-band emission and broad excitation spectra QDs are excellent donors for fluorescence resonance energy transfer (FRET)-based biosensors. Several sensor designs based on FRET between QDs and dye-labeled biomolecules have been developed. ${ }^{11-13}$ For example, Mauro et al. designed a maltosebinding assay based on FRET between CdSe/ZnS QDs and dye acceptors. ${ }^{11}$ A FRET TNT sensor was developed based on a hybrid QDs antibody fragment, ${ }^{12}$ and Gill et al. used FRET in CdSe/ZnSDNA conjugates to probe hybridization and DNA cleavage. ${ }^{13}$ More recently, QD and FRET-based protease sensors to measure extracellular matrix metalloproteinase activity have been reported. ${ }^{14}$

Homogeneous DNA fluorescence essays are a particularly versatile way to detect hybridization, but generally, labeling of two nucleic acids or dual modification of the same strand is necessary to achieve sequence specificity. Here we report a simple sensing platform to evaluate specific hybridization based on the FRET between luminescent CdTe QDs and dye-labeled single-stranded DNA (ssDNA) probes through a cationic polymer acting as an electrostatic linker (Scheme 1). Unlike the FRET-based sensors mentioned above, in this design covalent immobilization of the probe molecules is not required, and DNA sequence specificity was achieved with minimal probe modification.

Water-soluble CdTe QDs were prepared in aqueous solution by using thioglycolic acid as the capping ligand. ${ }^{9}$ After refluxing for $10 \mathrm{~min}$, the resulting CdTe QD colloid was irradiated for $12 \mathrm{~h}$ with a $150-\mathrm{W}$ xenon lamp at room temperature (see Supporting Information for details). During irradiation, the emission of CdTe QDs colloid progressively blue shifted, and the PL intensity increased due to the oxidation of Te atoms and the formation of a CdS shell. The negatively charged CdTe QDs were dissolved in a cationic polymer solution, poly(diallyldimethylammonium chloride) (PDADMAC), for $10 \mathrm{~min}$ to acquire positive surface charge. These positively charged CdTe QDs $\left(\mathrm{CdTe}^{+}\right)$had an emission peak at $497 \mathrm{~nm}$ with a fwhm of $45 \mathrm{~nm}$ (Figure 1).
Scheme 1. Principle of DNA Hybridization-Detection System Based on the QD/Cy3-labeled DNA FRET

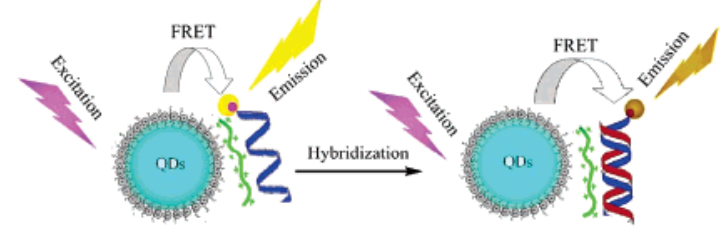

Cy3-labeled ssDNA (Cy3-DNA) was chosen as the acceptor. Although $\mathrm{Cy} 3$ is widely used for DNA labeling, it is rarely employed in FRET measurements with QDs because its emission peak overlaps with those of most commercially available QDs, and effective separation cannot be obtained. The absorption and emission spectra of Cy3-DNA in $100 \mathrm{mM} \mathrm{NaCl}$ and $50 \mathrm{mM}$ sodium citrate (SSC buffer, pH 7.8) are shown in Figure 1. The emission of $\mathrm{CdTe}^{+}$partly overlaps with the absorption spectrum of $\mathrm{Cy} 3$, suggesting that efficient FRET between them can take place. There is a little overlap between $\mathrm{CdTe}^{+}$and $\mathrm{Cy} 3$ emission, allowing effective separation. Indeed, in a solution of $\mathrm{CdTe}^{+}$and Cy3-labeled ssDNA, excitation of $\mathrm{CdTe}^{+}$at $360 \mathrm{~nm}$ results in efficient FRET to $\mathrm{Cy} 3$ (Figure 1). (Note that there is negligible direct emission from Cy3 upon excitation at $360 \mathrm{~nm}$.) There is a $10 \mathrm{~nm}$ red-shift in the Cy3 emission peak that can be explained by an increase in polarity in the vicinity of $\mathrm{Cy} 3$ due to the interaction with the cationic polymer. ${ }^{15,16}$ It is interesting to note that this is accompanied by a 10-nm blue-shift of the $\mathrm{CdTe}^{+}$emission. In a control experiment, no FRET between negatively charged CdTe QDs and Cy3 was detected (see Figure 2 of Supporting information), suggesting the electrostatic interactions play a key role to ensure proximity between donor and acceptor. The calculated FRET efficiency is 92\% according to $E=1-F_{\mathrm{DA}} / F_{\mathrm{D}}$, where $F_{\mathrm{DA}}$ and $F_{\mathrm{D}}$ are integrated fluorescence intensities of $\mathrm{CdTe}^{+}$in the presence or absence of the acceptor $\mathrm{Cy} 3$, respectively. ${ }^{17}$

In order to obtain high FRET efficiencies the excess of unbound cationic polymer PDADMAC in the $\mathrm{CdTe}^{+}$solution had to be minimized. An experiment was carried out by adding PDADMAC

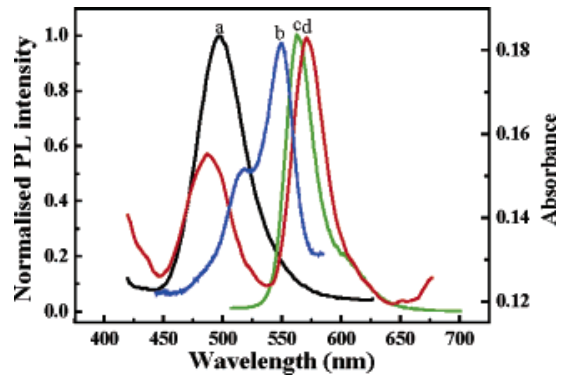

Figure 1. Normalized spectra of (a) emission of $\mathrm{CdTe}^{+}$excited at 360 $\mathrm{nm}$, (b) absorption of Cy3-DNA, (c) emissions of Cy3-DNA excited at 488 $\mathrm{nm}$, and (d) emission of $\mathrm{CdTe}^{+} / \mathrm{Cy} 3-\mathrm{DNA}$ excited at $360 \mathrm{~nm}$; All spectra were recorded in SSC buffer.

PAGE EST: AM. CHEM. SOC. XXXX, $X X X$, A 

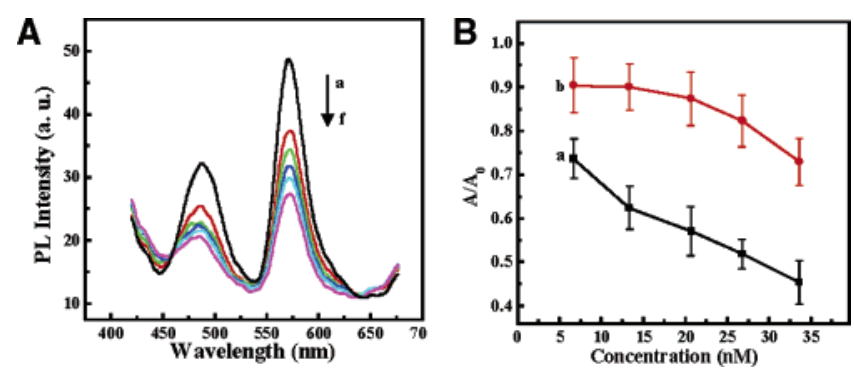

Figure 2. (A) Emission spectra of $\mathrm{CdTe}^{+} / \mathrm{Cy} 3-\mathrm{DNA}$ hybrid after hybridization with different concentrations of target. (a) $0 \mathrm{nM}$; (b) $6.7 \mathrm{nM}$; (c) 13.3 nM; (d) $20.2 \mathrm{nM}$; (e) $26.8 \mathrm{nM}$; (f) $33.6 \mathrm{nM}$. (B) Normalized fluorescence changes of Cy3-DNA after incubation with complementary (a) or noncomplementary DNA (b) samples. $A_{0}$ and $A$ are integrated areas of Cy3 before and after the incubation, respectively.

to a solution containing unmodified CdTe QDs and Cy3-DNA (see Figure 3 of Supporting information). Increasing the concentration of PDADMAC from $5.8 \times 10^{-6}$ wt $\%$ to $1.7 \times 10^{-5}$ wt $\%$ caused a small increase in the fluorescence intensity of $\mathrm{Cy} 3$, but when the concentration of PDADMAC reached $4.1 \times 10^{-5} \mathrm{wt} \%$, the fluorescence intensity of $\mathrm{Cy} 3$ began to decrease with a maximal FRET efficiency of $77 \%$. This result implies that Cy3-DNA prefers to interact with free PDADMAC molecules in the solution. In solution, the polymer chains have a conformation of a flexible random coil, which facilitates their interaction with ssDNA through electrostatic and hydrophobic interactions.

To study how the conjugation of $\mathrm{CdTe}^{+}$and $\mathrm{Cy3}$-DNA was affected by the presence of sample DNA, the hybrid of $\mathrm{CdTe}^{+}$and Cy3-DNA was incubated with different concentrations of complementary DNA at room temperature, and spectra were obtained after $30 \mathrm{~min}$ (Figure 2A). While the fluorescence intensity of $\mathrm{Cy} 3$ progressively decreased with increased concentration of complementary DNA (Figure 2A), the normalized integrated area showed a sample concentration-dependent decrease as shown in Figure 2B, indicating an increased distance between QDs and dsDNA. This may be explained by the more rigid DNA duplex structure as compared to ssDNA, which may increase the distance between polymer and dye, thus decreasing the FRET efficiency. Additionally, the increase in negative charge density due to the formation of a DNA duplex will increase the repulsive electrostatic forces between negatively charged CdTe QDs and DNA-Cy3, also resulting in larger distances and lower FRET efficiency.

After incubation with noncomplementary DNA, the fluorescence intensity of Cy3-DNA also decreases slightly (Figure 2B). This is probably due to the competition of added negatively charged noncomplementary DNA with Cy3-DNA in the CdTe ${ }^{+} / \mathrm{Cy} 3-\mathrm{DNA}$ duplex. It is clear, though, that noncomplementary DNA causes a much smaller change in the fluorescence intensity of $\mathrm{Cy} 3$ than corresponding concentrations of complementary DNA.

As noted above, the luminescent intensity of the $\mathrm{CdTe}^{+} / \mathrm{Cy} 3-$ DNA complex generally decreased with increasing concentrations of DNA, largely independent of the general FRET behavior. In order to understand this phenomenon, the interaction between
$\mathrm{CdTe}^{+}$and ssDNA was investigated. It was found that the addition of complementary DNA caused the decrease in luminescent intensity of $\mathrm{CdTe}^{+}$in the presence of high concentration of DNA probe (see Figure 4 of Supporting information) probably due to aggregation of QDs caused by hybridization.

Longer sequences of DNAs were used to evaluate the general usefulness of this sensing platform. Generally, similar results were obtained (see Figures 5 and 6 of Supporting information).

In summary, a simple DNA-sensing platform was developed on the basis of the FRET between blue-luminescent CdTe QDs and dye-labeled ssDNA. A cationic polymer acts as an "electrostatic linker" to achieve efficient energy transfer from the QD donor to the dye acceptor. The differential interaction of single-stranded and double-stranded DNA with $\mathrm{CdTe}^{+}$results in differential changes of FRET efficiency, which is used here to recognize the hybridization event. This platform provides a homogeneous DNA assay that has all the advantages of a solution-based fluorescence detection method, but requires only minimal DNA modification.

Acknowledgment. We greatly thank the Royal Society of New Zealand Marsden Fund for financial support of this research.

Supporting Information Available: Synthesis and modification of CdTe QDs, general experimental procedure, interaction between $\mathrm{CdTe}^{+}$and ssDNA, measurement of the amount of bound Cy3-DNA, and detection of longer DNA. This material is available free of charge via the Internet at http://pubs.acs.org.

\section{References}

(1) Bruchez, M., Jr; Moronne, M.; Gin, P.; Weiss, S.; Alivisatos, A. P. Science 1998, 281, 2013-2016.

(2) Chan, W. C.; Nie, S. Science 1998, 281, 2016-2018.

(3) Mattoussi, H.; Mauro, J. M.; Goldman, E. R.; Anderson, G. P.; Sundar, V. C.; Mikulec, F. V.; Bawendi, M. G. J. Am. Chem. Soc. 2000, 122, 12142-12150.

(4) Murray, C. B.; Norris, D. J.; Bawendi, M. G. J. Am. Chem. Soc. 1993 , $115,8706-8715$.

(5) Peng, X.; Schlamp, M. C.; Kadavanich, A. V.; Alivisatos, A. P. J. Am Chem. Soc. 1997, 119, 7019-7029.

(6) Reiss, P.; Bleuse, J.; Pron, A. Nano Lett. 2002, 2, 781-784.

(7) Dubertret, B.; Skourides, P.; Norris, David, J.; Noireaux, V.; Brivanlou, Ali, H.; Libchaber, A. Science 2002, 298, 1759-1762.

(8) Uyeda, H. T.; Medintz, I. L.; Jaiswal, J. K.; Simon, S. M.; Mattoussi, H J. Am. Chem. Soc. 2005, 127, 3870-3878.

(9) Rogach, A. L.; Katsikas, L.; Kornowski, A.; Su, D.; Eychmueller, A. Weller, H. Ber. Bunsen-Ges. 1996, 100, 1772-1778.

(10) Gaponik, N.; Talapin, D. V.; Rogach, A. L.; Hoppe, K.; Shevchenko, E V.; Kornowski, A.; Eychmueller, A.; Weller, H. J. Phys. Chem. B 2002, 106, 7177-7185.

(11) Medintz, I. L.; Clapp, A. R.; Mattoussi, H.; Goldman, E. R.; Fisher, B. Mauro, J. M. Nat. Mater. 2003, 2, 630-638.

(12) Goldman, E. R.; Medintz, I. L.; Whitley, J. L.; Hayhurst, A.; Clapp, A R.; Uyeda, H. T.; Deschamps, J. R.; Lassman, M. E.; Mattoussi, H. J. Am. Chem. Soc. 2005, 127, 6744-6751.

(13) Gill, R.; Willner, I.; Shweky, I.; Banin, U. J. Phys. Chem. B 2005, 109, $23715-23719$

(14) Shi, L.; De Paoli, V.; Rosenzweig, N.; Rosenzweig, Z. J. Am. Chem. Soc. 2006, 128, 10378-10379

(15) Gaylord, B. S.; Heeger, A. J.; Bazan, G. C. J. Am. Chem. Soc. 2003, 125, $896-900$

(16) Peng, H.; Soeller, C.; Travas-Sejdic, J. Chem. Commun. 2006, 37353737 .

(17) Clapp, A. R.; Medintz, I. L.; Mauro, J. M.; Fisher, B. R.; Bawendi, M. G.; Mattoussi, H. J. Am. Chem. Soc. 2004, 126, 301-310.

JA0685452 


\title{
Supporting Information for \\ DNA Hybridization Detection with Blue Luminescent Quantum Dots and Dye-Labeled Single-Stranded DNA
}

\author{
Hui Peng, Lijuan Zhang, Tanja H. M. Kjällman, Christian Soeller \\ and Jadranka Travas-Sejdic* \\ Polymer Electronic Research Centre, The University of Auckland, \\ Private Bag 92019, Auckland, New Zealand
}

\section{Materials}

Thioglycolic acid ( $\geq 98 \%), \mathrm{CdCl}_{2}$ (99.99\%), tellurium powder $(99.997 \%), \mathrm{NaBH}_{4}$ (95\%), poly(diallyldimethylammonium chloride) (PDADMAC) (very low molecular weight $<100000,35$ wt. $\%$ in $\mathrm{H}_{2} \mathrm{O}$ ) and Ultrafree-MC Microcentrifuge filters (NMWL 100,000Da, PTHK polysulfone membrane) were obtained from Sigma-Aldrich. The DNAs were purchased from Alpha DNA, Canada and the sequences are as follows:

Cy3-labelled probes:

5'-GAT GAG TAT TGA TGC CGA-Cy3 (18 base);

5'-GAT GAG TAT TGA TGC CGA GAT GAG TAT TGA TGC CGA -Cy3 (36 base); 5'-GAT GAG TAT TGA TGC CGA GAT GAG TAT TGA TGC CGA GAT GAG TAT TGA TGC CGA-Cy3 (54 base),

plain probe:

5'-GAT GAG TAT TGA TGC CGA-3', complementary targets:

5'-TCG GCA TCA ATA CTC ATC-3', 5'-TCG GCA TCA ATA CTC ATC TCG GCA TCA ATA CTC ATC -3', 5'-TCG GCA TCA ATA CTC ATC TCG GCA TCA ATA CTC ATC TCG GCA TCA ATA CTC ATC-3'

non-complementary: 5'- TAT GCT GGT GCG TCG CAC-3'

A quartz cell of $400 \mu \mathrm{L}$ volume was used for fluorescence measurement.

\section{Synthesis of CdTe QDs}

The synthesis of CdTe QDs was performed according to the reference ${ }^{1}$ with some modification. First, NaHTe was prepared by adding $40 \mathrm{mg} \mathrm{NaBH}$ to a flask containing 
$46 \mathrm{mg}$ tellurium powder and $2 \mathrm{ml}$ Milli-Q water under nitrogen atmosphere. The reaction was kept on for several hours until all tellurium powder was dissolved.

$0.092 \mathrm{~g}(0.5 \mathrm{mmol})$ of $\mathrm{CdCl}_{2}$ and $0.092 \mathrm{mg}(1 \mathrm{mmol})$ of thioglycolic acid were dissolved in $100 \mathrm{~mL}$ Milli-Q water, followed by adjusting $\mathrm{pH}$ to 8.2 by addition of $1 \mathrm{M}$ $\mathrm{NaOH}$ solution. The mixture was deaerated by $\mathrm{N}_{2}$ bubbling for $30 \mathrm{~min}$. Then $\mathrm{NaTeH}$ solution $(0.062 \mathrm{mmol})$ was quickly injected into the mixture under vigorous stirring, followed by refluxing the mixture for $10 \mathrm{~min}$ under open-air conditions.

The obtained CdTe colloid was irradiated using a $150 \mathrm{~W}$ xenon lamp with a water filter to attenuate the near infrared part of the spectrum. During irradiation, the PL intensity increased and the emission peak shifted towards the blue end of the spectrum, as shown in Figure 1. The irradiation promotes oxidation of unsaturated Te atoms which were identified as hole traps ${ }^{2}$ and are known to be highly susceptible to oxidation ${ }^{3}$.The oxidation of Te atoms leads to a decrease in particle size which results in a blue shift of absorption and emission peaks. At the same time, the irradiation causes the decomposition of TGA with release of sulfur to form a CdS shell around the CdTe core

${ }^{4}$, resulting in the enhancement of the PL efficiency ${ }^{5}$. The formation of a CdS shell alslo greatly inhibits further oxidation of CdTe QDs. Note: Highly luminescent CdTe QDs colloid can also be obtained by direct irradiation without refluxing, but require longer irradiation times.

\section{Modification of CdTe QDs}

$200 \mathrm{~mL}$ of 2-propanol was added to as-prepared CdTe QDs colloid solution. CdTe QDs were precipitated from the solution and collected by centrifugation. The obtained CdTe QDs were first dried at room temperature under vacuum and then redissolved in $50 \mathrm{~mL}$ of PDADMAC solution (0.35 wt. \%, pH 7.0) for $10 \mathrm{~min} .150 \mathrm{~mL}$ of 2-propanol was added to precipitate the QDs. After centrifugation, the QDs were dissolved in 50 $\mathrm{mL}$ of Milli-Q water. The procedure was repeated to remove any unbounded polymer. The finally obtained positively charged CdTe QDs $\left(\mathrm{CdTe}^{+}\right)$were dispersed in $100 \mathrm{~mL}$ of SSC buffer (100 mM NaCl and $50 \mathrm{mM}$ sodium citrate, $\mathrm{pH} 7.8)$ and used for the subsequent experiments.

\section{General Experimental Procedure}

$5 \mu \mathrm{L}$ of Cy3-DNA $(31.55 \mu \mathrm{M})$ was added to $295 \mu \mathrm{L}$ of $\mathrm{SSC}$ buffer solution containing $20 \mu \mathrm{L}$ of PDADMAC modified CdTe QDs and the mixture was kept for 5 
min to form $\mathrm{Cy} 3-\mathrm{DNA} / \mathrm{CdTe}^{+}$hybrid before fluorescence measurement. For DNA sensing, $5 \mu \mathrm{L}$ of DNA sample solutions with different concentrations were added to the solution containing Cy3-DNA/ $\mathrm{CdTe}^{+}$hybrid prepared as described above and kept for half an hour at room temperature. SSC buffer containing $100 \mathrm{mM} \mathrm{NaCl}$ and $50 \mathrm{mM}$ sodium citrate ( $\mathrm{pH} 7.8$ ) was used throughout. All spectra were recorded with a PerkinElmer LS55 luminescence spectrometer at an excitation wavelength of $360 \mathrm{~nm}$.

\section{Measurement of the Amount of Cy3-DNAs Bound with $\mathrm{CdTe}^{+}$QDs}

$5 \mu \mathrm{L}$ of Cy3-DNA $(31.55 \mu \mathrm{M})$ was added to $295 \mu \mathrm{L}$ of SSC buffer solution containing $20 \mu \mathrm{L}$ of $\mathrm{CdTe}^{+}$QDs and the mixture was kept for $5 \mathrm{~min}$. Then the mixture was transferred to an Ultrafree-MC Microcentrifuge filter (NMWL 100,000Da). Cy3-DNA/ $\mathrm{CdTe}^{+}$hybrid was separated from the solution by centrifugation at $7000 \mathrm{~g}$ for $8 \mathrm{~min}$. The absorbance of the filtrate solution at $260 \mathrm{~nm}$ was measured by using a Shimadzu UV-1700 Spectrophotometer. The absorbance of $300 \mu \mathrm{L}$ of SSC buffer containing $5 \mu \mathrm{L}$ of Cy3-DNA $(31.55 \mu \mathrm{M})$ at $260 \mathrm{~nm}$ was also measured. The amount of Cy3-DNAs bound with $\mathrm{CdTe}^{+}$QDs was calculated by using the change in the absorbance. The result revealed that $0.132 \mathrm{nmol}$ of Cy3-DNA $(440 \mathrm{nM})$ was bound with the given amount of $\mathrm{CdTe}^{+}$QDs after adding of $5 \mu \mathrm{L}$ of Cy3-DNA $(31.55 \mu \mathrm{M})$. This also means that $84 \%$ of added Cy3-DNA was bound with $\mathrm{CdTe}^{+}$QDs.
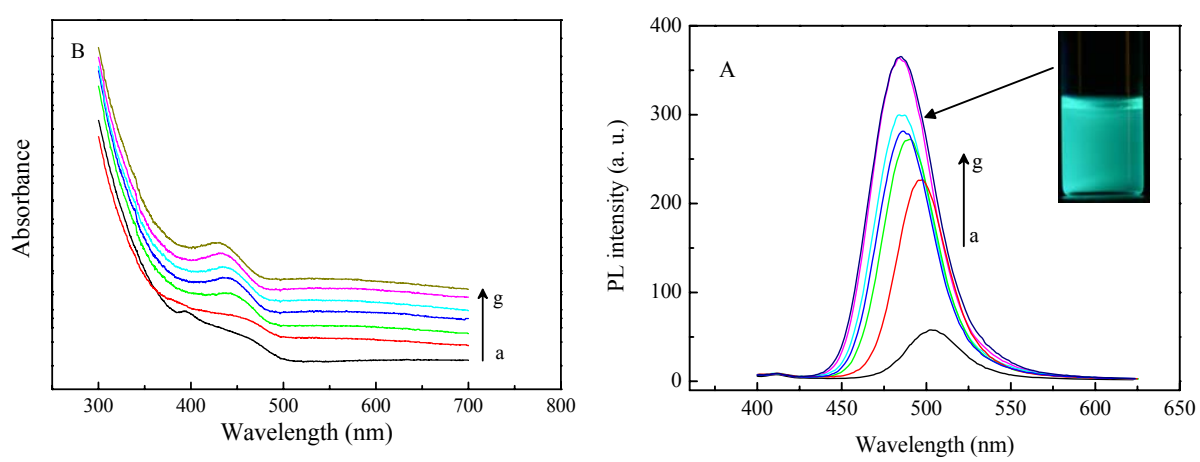

Figure 1. Emission spectra (A) and absorption spectra (B) of CdTe QDs colloid solutions during irradiation. (a) $0 \mathrm{~h}$; (b) $2 \mathrm{~h}$; (c) $6 \mathrm{~h}$; (d) $8 \mathrm{~h}$; (e) $10 \mathrm{~h}$; (f) $12 \mathrm{~h}$; (g) 14 h. Inset: photo of CdTe QDs colloid solution after irradiation of $14 \mathrm{~h}$, excited at $365 \mathrm{~nm}$ by using a UV lamp. 


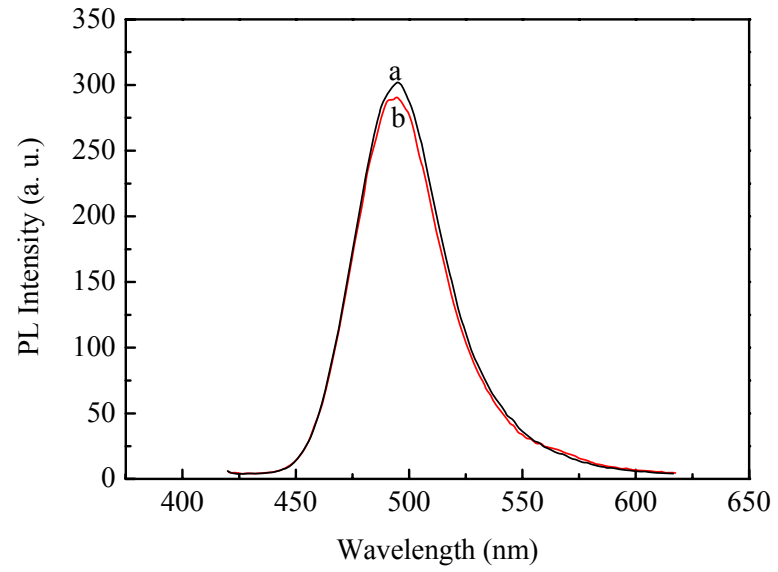

Figure 2. Emission spectra of unmodified CdTe QDs excited at $360 \mathrm{~nm}$. (a) without Cy3-DNA; (b) in the presence of Cy3DNA $(0.53 \mu \mathrm{M})$.

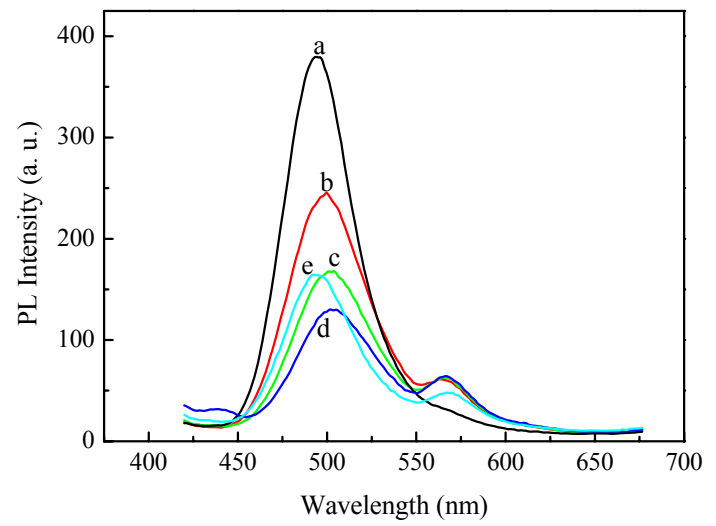

Figure 3. Emission spectra of the solution containing unmodified CdTe QDs and $0.53 \mu \mathrm{M}$ of Cy3-DNA after continuous addition of PDADMAC solution. Excitation wavelength is $360 \mathrm{~nm}$. The volume of PDADMAC solution $\left(3.5 \times 10^{-4}\right.$ wt. \%) added to the solution: (a) $0 \mu \mathrm{L}$; (b) $5 \mu \mathrm{L}$; (c): $10 \mu \mathrm{L}$; (d): $15 \mu \mathrm{L}$; (e) $35 \mu \mathrm{L}$. 


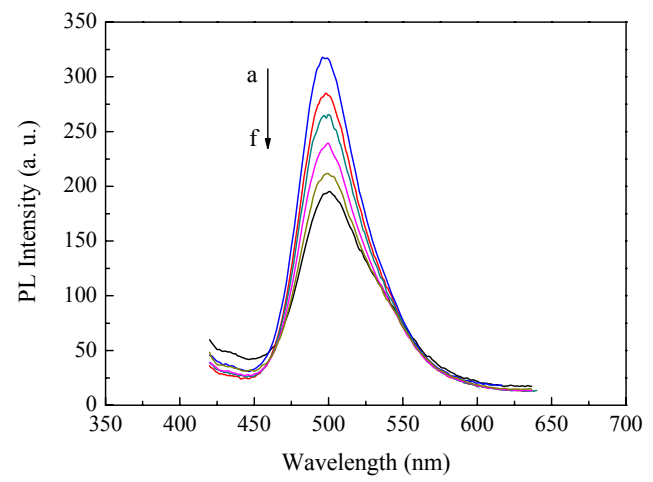

Figure 4 Emission spectra of the solution containing $\mathrm{CdTe}^{+}, 0.528 \mu \mathrm{M}$ probe without Cy3 labelling and different concentrations of complementary DNA. (a) 0 nM; (b) $6.7 \mathrm{nM}$; (c) $13.3 \mathrm{nM}$; (d) $20.2 \mathrm{nM}$; (e) $26.8 \mathrm{nM}$; (f) $33.6 \mathrm{nM}$.

\section{Evaluation of the sensing approach for detection of longer DNA sequences}

The effectiveness of the suggested DNA detection platform was additionally evaluated by using longer Cy3 labelled DNAs (36 base and 54 base) and corresponding complementary targets. Similar results to those discussed above were obtained, as shown in Figure 5 and 6 . The FRET efficiencies are $83 \%$ and $79 \%$ for Cy3-DNA with 36 bases and 54 bases, respectively. The decrease of FRET efficiency with the increase of DNA length is probably due to the larger volume of longer sequences, which increases the average distance between QDs and the dye.

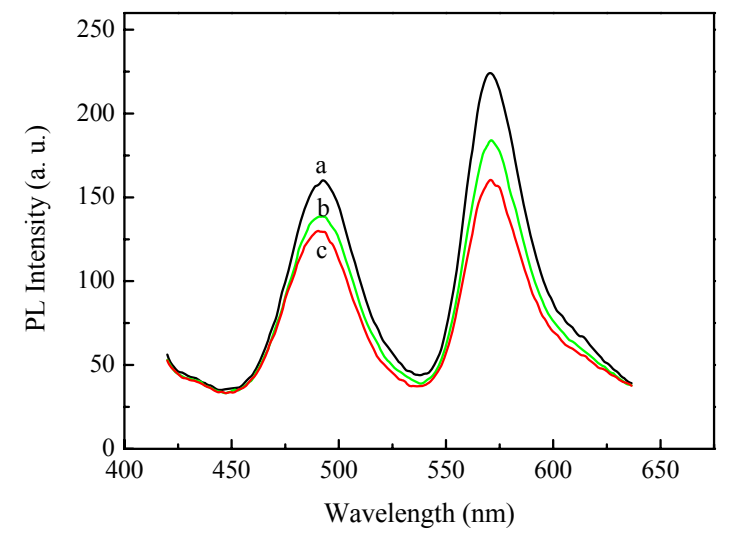

Figure 5 Emission spectra of $\mathrm{CdTe}^{+} / \mathrm{Cy} 3-\mathrm{DNA}$ (36 base) hybrid after hybridization with different concentration of corresponding target. a: $0 \mathrm{nM}$; b:6.7 nM; c: $13.3 \mathrm{nM}$; 


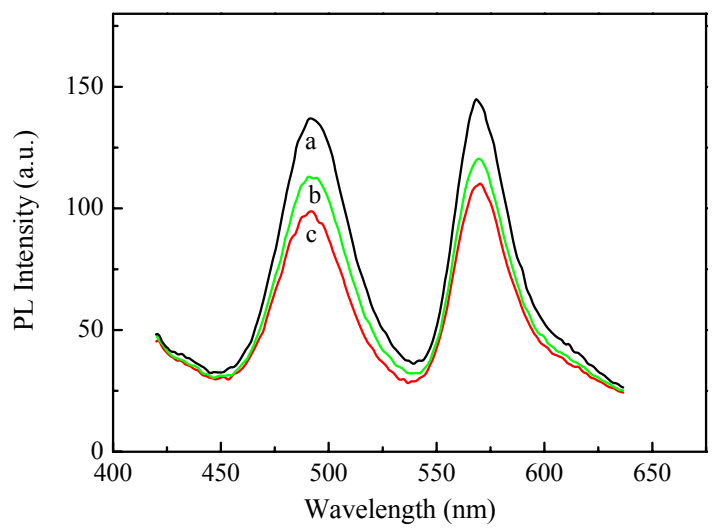

Figure 6 Emission spectra of $\mathrm{CdTe}^{+} / \mathrm{Cy} 3-\mathrm{DNA}$ (54 base) hybrid after hybridization with different concentration of corresponding target. a: $0 \mathrm{nM}$; b:6.7 nM; c: $13.3 \mathrm{nM}$;

Reference:

(1) Rogach, A. L.; Katsikas, L.; Kornowski, A.; Su, D.; Eychmueller, A.; Weller, H. Berichte der Bunsen-Gesellschaft 1996, 100, 1772-1778.

(2) Glozman, A.; Lifshitz, E.; Hoppe, K.; Rogach, A. L.; Weller, H.; Echymuller, A. Isr. J. Chem. 2001, 41, 39-44.

(3) Resch, U.; Weller, H.; Henglein, A. Langmuir 1989, 5, 1015-1020.

(4) Bao, H.; Gong, Y.; Li, Z.; Gao, M. Chem. Mater. 2004, 16, 3853-3859.

(5) Peng, X.; Schlamp, M. C.; Kadavanich, A. V.; Alivisatos, A. P. J. Am. Chem. Soc. 1997, 119, 7019-7029. 